\title{
Being a truck driver in Brazil: From implicit self-stereotypes to system justification
}

\author{
Ser caminhoneiro no Brasil: dos autoestereótipos \\ implícitos à justificação de sistema
}

\author{
João Carlos MESSIAS ${ }^{1}$ iD) 0000-0002-6487-4407 \\ Hector CAVIERES-HIGUERA ${ }^{2}$ iD 0000-0001-7506-9692 \\ Ramon Araújo SILVA ${ }^{1}$ (D) 0000-0003-3649-5108 \\ Gabriela Nogueira de Senna FACUNDO3 ${ }^{3}$ (D) 0000-0001-7466-9549 \\ Renata Thurler LESSA ${ }^{3}$ (ID) 0000-0001-7256-8293
}

\begin{abstract}
Close to two million people currently work in Brazil's road transport sector, the country's leading logistical area. Most are self-employed individuals. The objective of this research project was to garner an understanding of the perceptions that Brazilian truck drivers hold regarding themselves. Eight experienced drivers were interviewed, starting from the question "What is it like being a truck driver in Brazil?", and their responses were analyzed in accordance with social discourse studies. Five main categories - with specific subdivisions - were identified, relating to motivations to work in this area, contextual elements, and positive, group, and negative self-image. It is concluded that self-stereotypes play an important role in maintaining the situation of disadvantage and precarious working conditions that affect truck drivers.
\end{abstract}

Keywords: Applied psychology; Mental health; Work; Workload; Workplaces.

\section{Resumo}

Atualmente cerca de dois milhões de trabalhadores estão envolvidos com o transporte rodoviário, a principal modalidade logística do Brasil, sendo a maioria deles, autônomos. Esta pesquisa teve como objetivo compreender a percepção que

$\boldsymbol{\nabla} \mathbf{\nabla} \boldsymbol{\nabla}$

1 Pontifícia Universidade Católica de Campinas, Centro de Ciências da Vida, Programa de Pós-Graduação em Psicologia. Av. John Boyd Dunlop, s/n., Prédio Administrativo CCV, Jardim Ipaussurama, 13060-904, Campinas, SP, Brasil. Correspondência para/Correspondence to: J.C. MESSIAS. E-mail: <joao.messias@puc-campinas.edu.br>.

2 Universidad Católica Silva Henríquez, Escuela de Investigación, Postgrado Facultad de Ciencias Sociales Jurídicas y Económicas. Santiago, Chile.

3 Pontifícia Universidade Católica de Campinas, Centro de Ciências da Vida, Curso de Psicologia, Campinas, SP, Brasil. Support: This study was financed in part by the Coordenação de Aperfeiçoamento de Pessoal de Nível Superior (Finance Code 001).

$\mathbf{\nabla} \mathbf{\nabla} \boldsymbol{\nabla}$

Como citar este artigo/How to cite this article

Messias, J. C., Cavieres-Higuera, H., Silva, R. A., Facundo, G. N. S., \& Lessa, R. T. (2019). Being a truck driver in Brazil: from implicit self-stereotypes to system justification. Estudos de Psicologia (Campinas), 36, e180139. http://dx.doi.org/10.1590/1982-02 75201936 el 180139 
os caminhoneiros brasileiros têm de si próprios. Oito condutores experientes foram entrevistados a partir da questão "como é ser caminhoneiro no Brasil?" e seus depoimentos foram analisados de acordo com a investigação social de discurso. Cinco categorias principais foram encontradas, com subdivisões específicas, relacionadas com motivações para o trabalho, elementos contextuais, autoimagem positiva, grupal e negativa. Conclui-se que os autoestereótipos exercem importante papel na manutenção da situação de desvantagem e de precárias condições laborais deles.

Palavras-chave: Psicologia aplicada; Saúde mental; Trabalho; Carga de trabalho; Local de trabalho.

The road logistics sector currently accounts for $61 \%$ of freight and $95 \%$ of passenger transport in Brazil. Further complexity is added by the continent-spanning size of the country, with the vast contrasts that this implies. The Brazilian road network includes $212,866 \mathrm{~km}$ of paved roads as well as 1,365,426 km of unpaved roads, with many stretches in an extremely poor state of preservation and infrastructure. The World Economic Forum places Brazil 103rd out of 137 countries in terms of infrastructure, trailing behind its Latin American peers - Chile (24th), Ecuador (29th), Uruguay (95th), and Argentina (96th) (Confederação Nacional do Transporte, Serviço Social do Transporte, \& Serviço Nacional de Aprendizagem do Transporte, 2017).

A report issued by the Agência Nacional de Transportes Terrestres (ANTT, Brazilian National Ground Transport Agency) shows total registrations in the Registro Nacional de Transportadores Rodoviários de Cargas (RNTRC, National Road Freight Transport Registry) as of late 2016, comprising a total of 783,947 transporters, being 622,328 self-employed professionals, 161,264 companies, and 355 cooperatives, with a combined fleet of 1,975,871 vehicles (Associação Nacional de Transportes Terrestres, 2019). This equates to some two million workers, with a significant proportion of them being subcontracted self-employed professionals.

Although truck driving is a profession that goes back many decades, it was first regulated in 2012. The Classificação Brasileira de Ocupações (CBO, Brazilian Classification of Occupations) defines the role as the activity of individuals who transport, collect, and deliver freight, pick up broken-down vehicles, provide mechanical assistance, verify documentation, plan routes, and oversee safety procedures and regulations (Ministério do Trabalho, 2014). They may be employees of transportation companies or self-employed truck drivers.

These independent workers have no links or assurance of rights under the regulations of the Consolidação das Leis do Trabalho (CLT, Consolidation of Labor Laws), comprising Transportadores Autônomos de Cargas (TACs, Independent Freight Transporters) and Auxiliary TAC (Presidência da República, 2007), who are subcontracted by the former and paid by the amount of work that they accomplish. All of these individuals are under pressure to accept severely degrading working conditions, such as extremely lengthy workdays, severe difficulty in changing their vehicles, or undertaking regular checks or safety items. Their own wellbeing is a secondary concern, even in terms of calculating costs, with fuel expenses making up a far larger proportion of freight costs than the workers' own income (Araújo, Bandeira, \& Campos, 2014).

A recent survey by the Confederação Nacional de Transportes (CNT, National Transport Confederation) offers a general profile of the category (Confederação Nacional de Transportes, 2016). Contrasting with the more general outlook of the ANTT, this project addressed a sample of 1066 individuals concentrating on the independent workers in the industry (68.4\%). Almost all are men, and most are aged 30-50, have completed Elementary school, have between 15 and 18 years of experience, and earn a net income between $\mathrm{R} \$ 3.300,00$ and $\mathrm{R} \$ 4.100,00$; around half of them are in debt and have observed a drop in the demand due to the financial crisis. Most drive around 10,000km per month, working an average of 11 hours per day.

Moreno and Rotenberg (2009) present two main profiles of professional drivers: those who are engaged in collecting and delivering goods within their own region or neighboring areas, and those who cover long distances, spending lengthy periods away from home. These two groups exhibit very different 2 routines and conditions, as the former work mainly during the daytime, stay relatively close to their cities, 
and make short journeys to neighboring cities only when necessary. The latter drive for far longer periods non-stop, working day and night under pressure due to delivery deadlines and in poor working conditions. This is the group under investigation in this project.

Many studies exist describing truck drivers' working conditions in a wide range of countries. Williams Jr., Thomas, and Liao-Troth (2017) have identified four main categories of workplace stressors: (1) loneliness and missing their families, which has a severe impact on their personal feelings; (2) health-related issues, in terms of both infrastructure-related security and not enough medical care; (3) a feeling of lacking respect, from people in general or related workers such as shipping professionals; and (4) government regulations.

This issue of loneliness is closely linked to fatigue and exhaustion, representing a clear hazard. Meanwhile, truck drivers frequently resort to using amphetamines, cocaine, or other stimulants in order to be able to handle long periods behind the wheel (Belan, Oliveira, Machado, Brandão, \& Silva, 2016). Conversely, boredom can drive them to take part in small secondary tasks such as checking social networks on their cellphones, changing the music they are listening to, looking at documents, and other similar activities, in a bid to break the monotony of the road (Iseland, Johansson, Skoog, \& Daderman, 2018).

Health issues have been investigated with a range of outlooks and contexts. Even developed countries such as the United States have been found to lack adequate infrastructure along their roads (Lincoln et al., 2018), with severe limitation on sites offering bathing facilities, exercise equipment, or healthy food. Concerns about sleep quality linked to stress (Guglielmi, Magnavita, \& Garbarino, 2017) sexual behavior, culture, and AIDS prevention campaigns (Sobrinho-Santos, Silva, Malheiros, Trindade, \& Pagan, 2015) have also received attention from the perspective of other studies.

Martins and Agli (2014) conducted a study into truck drivers' values, classifying them into three categories: (1) with no moral content, such as maintaining a good appearance (trimmed beard and combed hair, for example); (2) with moral content, values relating to prudence, responsibility, and respect for driving regulations; and (3) with ethical content, more closely linked to honesty, collaboration, and professionalism. Many truck drivers therefore resent the lack of respect that they experience in everyday situations.

Apart from the contractual regulations mentioned above, requirements for a person to become a professional driver in Brazil are less strict the ones in the United States, Canada, the United Kingdom, or Australia. A person can start driving heavy duty vehicles at an early age (around 20), which may constitute a risk factor, as evidence shows that more experienced (and more mature) professionals have a lower accident rate (Girotto, Andrade, González, \& Mesas, 2016).

\section{System Justification theory}

Many sociologists have spent significant energy in efforts to explain how social arrangements are validated or legitimized by the people who participate in them (Berkel, Crandall, Eidelman \& Blanchar, 2015; Sidanius, Levin, Federico, \& Pratto, 2001). In a sense, the sociological explanation describes the source of this validation as an interplay between groups in a position of advantage, power, or privilege, and others that are at a comparative disadvantage. The groups that hold a position of power are believed to generate mechanisms that can in some way pressure others to accept the legitimacy of their own subordination (Moscovici, 1996; Greenwald \& Banaji, 2017; Sidanius, Cotterill, Sheehy-Skeffington, Kteily, \& Carvacho, 2017).

More classical and individual psychology has also made inroads into exploring how individuals generate strategies for accepting disadvantageous situations, mechanisms for eliminating psychological conflict as investigated with the theory of cognitive dissonance, or defense mechanisms developed through psychoanalysis; more extreme theories like learned despair also show how people can come to accept clearly disadvantageous situations (Friesen, Kay, Eibach, \& Galinsky, 2014; Heiphetz, Spelke, \& Banaji, 2014). 
The comprehensive readings described above represent what in the field of social sciences have come to be known as biases; on the one hand, sociological explanations provide their own perspective in which individuals appear to be largely determined by social structures. Meanwhile, the psychological sciences set out to explain societies through mechanisms that operate on an individual level, in which an individual can at some point reach a breaking point from their environment, which then ceases to influence their behavior (Munné, 1993).

Nonetheless, social psychology developments within an approach compatible with psycho-social perspectives have applied a framework of analyzing relations between groups to address how the oppressed are able to generate strategies to maintain a positive self-image, with repercussions on the validation of the social order. Such developments are generally found in extensions of the theory of social identity propounded by Henry Tajfel, such as mechanisms for overcoming a negative social identity (Cavieres-Higuera \& CheyreTriat, 2016), the social dominance theory, or the system justification theory addressed in this analysis.

The system justification theory proposed by Jost and Banaji studies how the operation of people's implicit self-stereotypes within groups can generate negative self-images that validate their position of disadvantage, which the subjects are not conscious of being at, and that may be linked to what has been dubbed as false conscience. False conscience is seen as a suite of implicit self-stereotypes that may be capable of supporting social inequalities from the perspective of those who are at a disadvantage (Jost \& Banaji, 1994; Jost, Gaucher, \& Stern, 2015).

This theory proposes that a stereotype can serve as a source of justification on three levels, as a means of justifying behavior (Haack \& Sieweke, 2018). The interpersonal level: the subject's own stereotype operates to explain personal behavior, in line with individual psychological mechanisms such as those linked to cognitive dissonance, when an item becomes intolerable or incoherent with the individual's self-image, tending to look for an explanation for the action in other factors and not in themselves, as in the case of projection as a defense mechanism.

The inter-group level: the stereotype now justifies actions not by the individual but rather by the group, such as discriminatory attitudes derived from prejudice, when the group engaged in discrimination tends not to "see" or accept itself as a discriminatory collective, but rather the stereotype of the group subject to discrimination allows it to explain and cast its conduct, with prejudice underpinning discriminatory actions as something natural, something that the other group deserves (Haack \& Sieweke, 2018).

The system level: the stereotype explains not only inter-group behavior but also the system as a whole; indeed, beyond simply addressing an element of inter-group relations, it explains the framework that underpins inter-group relations in general, bringing implications in the legitimization of the social order (Haack \& Sieweke, 2018).

The system level thus operates on groups that are at a clear position of disadvantage and that therefore require more extreme mechanisms to justify their position, in order to be able to maintain a favorable selfimage; this means that they will necessarily have content items that work in practice, but with implications of which the individuals themselves are unaware (Jost, Banaji, \& Nosek, 2004; Sidanius et al., 2001; Jost et al., 2015).

This psycho-social and inter-group theory best allows for a deeper understanding of social categories and self-descriptions around which the collective of people labeled as truck drivers build implicit stereotypes that can legitimize their position of social disadvantage. The model is applied in the ways in which the group in question can be seen as a collective, as its members can be observed to see themselves as a group, thus suggesting that certain elements of their personal self-esteem are linked to belonging to the group of truck 4 drivers. 
Meanwhile, this proposed characterization could be seen to indicate that the group is at a clear social disadvantage, even in terms of the legal structure that underpins its members' working life. Finally, from a theoretical perspective, a contribution can be gained by examining the phenomenon through the lens of psycho-social frameworks linking individual and collective elements simultaneously.

\section{Method}

The research perspective is based on a qualitative methodology, and the study was conducted within the framework of social discourse research (Cottet, 2006). This approach is built on the theory that discourses represent the social position of the speakers, as a core element of the psycho-social understanding that supports the theory of system justification, in which social positions of advantage and disadvantage are held to mark differences in the ways in which stereotypes operate.

Data were collected using open interviews, with the goal of allowing subjects to expound on and explain their social positions (Ortí, 1996). The objective of understanding the perceptions that Brazilian truck drivers hold regarding themselves led to all interviews starting with the question "what is it like being a truck driver in Brazil?" All interviews were recorded and transcribed for subsequent analysis.

Social discourse analysis centers on interpreting speech as a topological device were used to situate the speaker's location in the social structure. These analyses included a survey of categories that could be taken as implicit self-stereotypes, which were then analyzed in terms of their capacity to legitimize the social order, in line with the tenets of the system justification theory (Cottet, 2006).

The project included interviews with eight drivers (Table 1), all of them over 40 years old (with a mean age of 52), with at least ten years of experience in the profession and a mean of 27 years of experience, making them seasoned workers. Seven of the eight drivers are married with children, and all have attained only low levels of formal education.

The conversations were held at a supply depot where drivers wait to receive their loaded trucks (a process that can sometimes take days) and took place during a two-week period in July 2018, just after the end of an eleven-day truck drivers' strike that had repercussions throughout the country. Drivers were calling for better working conditions, review of contractual issues, costs (such as toll and fuel costs), and freight tariffs. Although the functioning of the country suffered severe impacts, the truck drivers failed to achieve significant results. This study was approved by the Research Ethics Committee of PUC-Campinas (CEP\# 35508214.3.0000.548). All participants signed the Informed Consent Term, and pseudonyms were used for ethical reasons.

Table 1

Profile of the participants

\begin{tabular}{|c|c|c|c|c|c|}
\hline Pseudonym & Age & Experience (years of work) & Education level & Marital status & Children \\
\hline Nilton & 53 & 10 & Elementary school & Married & 1 \\
\hline Dênis & 53 & 28 & Elementary school & Married & 2 \\
\hline Euclides & 63 & 38 & Elementary school & Married & 5 \\
\hline Josimar & 40 & 20 & Elementary school & Married & 1 \\
\hline Leonel & 48 & 30 & Elementary school & Married & 1 \\
\hline José augusto & 53 & 25 & Elementary school & Married & 3 \\
\hline Maurício & 65 & 44 & Elementary school & Married & 4 \\
\hline Ronaldo & 41 & 23 & Elementary school & Single & 0 \\
\hline
\end{tabular}

Note: Data compiled from the interviews. 


\section{Results}

Data gathered from the interviews with truck drivers were organized into five major categories, with certain specificities or subcategories (Table 2). A brief explanation of each item is presented below.

The first category addresses the subjects' reasons for working as truck drivers - curiously, their responses can be divided into two apparently opposite subcategories. One carries a negative tone of a lack of opportunities: "I'm here because I don't know how to do anything else; if I did, I wouldn't be driving" (Nilton); while the other one is linked to a kind of love for the profession: "The first thing is liking it, you have to do what you enjoy or else you'd quit on the first trip" (Maurício).

The category of contextual elements also shows varying visions, with one centered on political, economic, and setting-based elements: "No, no, no... they make the laws and there are no conditions at all... The government doesn't offer conditions, it has to be them, them and congress, but they don't do anything" (José Augusto). The other group focuses on the psychological context, with an emphasis on pressure and stress: "The moment when the truck gets going, loaded or empty, the psychological pressure starts" (Leonel).

The third category relates to the interviewees' positive elements of self-image. These self-images are associated with a somewhat romantic and at times altruistic vision: "You do whatever it takes to help human beings" (Euclides), or heroically resigned: "A trucker's life is the life of a hero ... you have to be everything, a puncture repair man, a mechanic, and an assistant, a real Jack-of-all-trades, and you have to do it to survive" (Mauricio).

Another facet relates to the economic importance of their work: "Drugstores, malls, butchers, bakers, liquor stores, everything. You know, everything depends on trucks" (Leonel). Truck drivers hold a very strong perception about themselves as a union of workers, built on the idea of disunity: "Disunity. That's all. Because if the truckers were united, things would have changed a long time ago. But there's no union. Truckers fight with each other to get a load to haul" (Nilton), "Every man for himself, and God for all" (Leonel).

The last category is the largest and perhaps the most present in discourse: negative self-image, broken down into four subdivisions. In general, these elements are related to material aspects, as well as subjective

Table 2

Content categories and subcategories

\begin{tabular}{|c|c|}
\hline Categories & Subcategories \\
\hline \multirow{2}{*}{ Reasons for taking the job } & Low formal education and lack of opportunities \\
\hline & Personal preference \\
\hline \multirow{2}{*}{ Contextual elements } & External, political, economic context \\
\hline & Psychological context of high demand \\
\hline \multirow{2}{*}{ Positive image } & Anonymous hero \\
\hline & Driving the economy \\
\hline Group image & Lack of union \\
\hline \multirow{4}{*}{ Negative image } & Discriminatory actions \\
\hline & Structural aspects of exclusion \\
\hline & Subjective aspects of exclusion \\
\hline & Stereotypes \\
\hline
\end{tabular}


concepts such as discrimination and exclusion. The first subdivision - discriminatory actions - concerns specific cases of mistreatment and experiences of degrading working conditions: "Often the water is cold, and you still have to pay the same for using the bathroom" (Maurício).

The second subcategory draws together structural aspects of exclusion, the more concrete ways in which these processes operate: "When you're there in the air conditioning of the supermarket, doing your shopping, the storage room is out there at the back: that's where the truckers are roasting in the sun, waiting to unload. No bathroom, no water, no food" (Leonel). These two subcategories are associated with the more material elements.

Meanwhile, the other subcategories relate to more psychological and emotional perspectives. The third one relates to subjective aspects of exclusion, filled with situations of humiliation: "And you can see you're not valued... sure it's humiliating... no, it's not easy at all ..." (Dênis); suspicion: "Passersby start accusing truckers without knowing anything, they always put the blame on the driver, the guy was asleep, he was drunk, stoned, that's the first thing they talk about..." (Maurício), lack of respect: "[Truck drivers are] ... not respected, even today. Wherever you go there's no respect" (Josimar) and lack of recognition: "Hey, society doesn't see truckers the way it ought to, you get me?" (Nilton).

The final subcategory concerns stereotypes that truck drivers hold about themselves, although some of these are at times nebulous, such as the idea that they are drug users: "And people on the outside say 'he's a junkie, he's a drug addict, because they don't know, they're not stuck sitting there as night falls... try living the life of people who have to work to support their families..." (Maurício), lazy or old: "Nowadays there are no young people who want to drive trucks, you can look around at truck stops, most are older guys" (Leonel).

\section{Discussion}

The profile of the interviewees seems to constitute a fairly close reflection of the characteristics of workers in the sector, according to information published by the National Transport Confederation (CNT, 2016), in terms of formal education, sex, connection with the job, and workload. However, these subjects are somewhat older and more experienced than the average truck driver.

It is possible that the profession's poor working conditions are making it less attractive for young people, as Leonel observed, particularly those who obtained greater opportunities to complete their education, thus pushing average ages up. Nonetheless, one positive aspect of this phenomenon is that more experienced drivers tend to have fewer accidents, as noted by Girotto et al. (2016). There is also a link here with the first category listed, covering motivation from a paradoxical perspective: drivers mention a lack of options to do other things, and yet, at the same time, a contrasting and romantic vision of freedom and adventure.

The contextual aspects are in line with the findings shown in other publications. Participants frequently spoke of deep-seated dissatisfaction with political and economic issues, together with a recurring desire for the government to do something for them. Governmental regulations constitute one of the sources of stress found by Williams Jr. et al. (2017). This area is also linked to the concept of a work-related locus of control (Zigarmi, Galloway, \& Roberts, 2018). In this case, truck drivers have been found to hold a general perception of an external locus (government, God, luck) regarding the decisive issues in their everyday lives, which constitutes a factor in wearing them down.

A high demand defines the psychological facet of the contextual elements. It is clear that the pressure associated with tight delivery deadlines has major repercussions on quality of work life amongst truck drivers. This stress makes them more likely to take stimulant substances, as they engage in a job that entails boredom and loneliness, as found by Belan et al. (2016) and Iseland et al. (2018). 
One significant item that can be noted in this analysis relates to both implicit and explicit stereotypes in the categories identified. The explicit stereotypes are the conscious self-descriptions that are generally attributed to perceptions amongst people who are not truck drivers themselves: the out-group, the other, as explained by Jost and Banaji (1994), and Jost et al. (2004). This can be noted in the categories of self-image (positive, group, and negative) that include interpersonal or inter-group aspects to a certain extent in terms of classification (Jost et al. 2015).

While truck drivers are aware of these stereotypes, they do not share them, and generally consider them to be rooted in a lack of awareness of their actual situation. Indeed, and in line with the observations of Jost et al. (2004), implicit stereotypes can be noted in the categories that truck drivers are not aware of possessing, or at least when the drivers themselves are not aware of the implications of these self-perceptions to legitimize their disadvantaged social position, within the framework of a social order that disadvantages them.

These theories take on relevance when it is noted that trucks drivers are, as a group, placed in a situation of clear social disadvantage, raising the question of how the group manages to overcome the situation in their everyday lives, to make sense of a job that exists within the framework of the described context complexities (Cavieres-Higuera \& Cheyre-Triat, 2016).

In this case, such considerations center on the categories shown for positive self-image amongst the individuals. The idea that they are a driving force for the economy, casting them as anonymous heroes, endows them with a significant social task that encourages them to overload themselves. Once again, drugs and stimulants are cast as common resources for achieving something superhuman (Girotto, Mesas, Andrade, \& Birolim, 2014).

In order to understand the power of these self-images to legitimize the existing situation, the key question to be asked is: can the anonymous hero who drives the Brazilian economy forgo this role? Can he afford the luxury of complaining to the extent of stopping doing his job for long enough that the conditions under which he works would change? The answer is clear: he cannot.

In contrast, the negative self-image also restricts drivers, who collaborate in allowing the mechanisms of discrimination and exclusion to take full effect. Indeed, Lincon et al. (2018) described the very weak infrastructure conditions that exist in the United States, a highly developed country. The contemporary conditions in Brazil are even worse: mistreatment, prejudice, and disrespect spark a severe resentment, which is echoed in the findings of Martins and Agli (2014) or Williams Jr. et al. (2017).

\section{Final Consideration}

Truck drivers represent an extremely numerous group of workers who play a crucial role in the Brazilian economy, which relies heavily on road transport. Despite their numbers and the contributions made by their work, which play a vital role in the country's routine, they face extremely difficult working conditions. Long workdays, debts, the risk of accidents, hijackings, loneliness, and disrespect are common factors. Shortly before these interviews, they held a strike that had nationwide repercussions, but little change was achieved.

The question therefore arises as to what makes them keep on working despite the problems they face. The system justification theory offers a means of understanding the justification power of explicit notions in the structural conditions of their work lives, which also depends on their own actions and attitudes, and is seen as something that has almost no chance of changing at all. This context of self-image operation strengthens conceptions of the social surroundings, thus generating a scenario with no margin for modifying the extant situation, inhibiting any possibility of change to their setting, which is restricted to current conceptions, giving rise to a need for implicit self-stereotypes that validate a social position of disadvantage. 
This study set out to analyze meaningful elements that could clarify the reasons for acceptance of degrading working conditions amongst members of this group, which is recognized as being deeply disunited. Whether they are positive or negative, stereotypes can be observed to hamper the emergence of any more realistic means of calling for a fairer and more humane situation. Perhaps if truck drivers were able to see themselves not as heroes or bad guys, but rather as workers, they might be able to raise awareness for more dignified conditions and rights.

As this research project was qualitative in nature, its results cannot be taken as conclusive, but it is hoped that these findings may be relevant for raising awareness regarding the topic. In addition to economic aspects, it is important to analyze issues of road safety as well as quality of life for these workers. Further qualitative studies focusing on the perspectives perceived amongst different stakeholders in this process - such as truck drivers themselves, highway police, contracting parties, and shipping professionals, for example -, could be useful and are to be encouraged.

\section{Contributors}

All authors made significant contributions to this work.

\section{References}

Associação Nacional de Transportes Terrestres. (2019). Registro Nacional de Transportadores Rodoviários de Cargas. Recuperado em outubro 25, 2019, de http://www.antt.gov.br/cargas/arquivos_old/RNTRC.html

Araújo, M. P. S., Bandeira, R. A. M., \& Campos, V. B. G. (2014). Custos e fretes praticados no transporte rodoviário de cargas: uma análise comparativa entre autônomos e empresas. Journal of Transport Literature, 8(4), 187-226. http:// dx.doi.org/10.1590/2238-1031.jtl.v8n4a8

Belan, T. O., Oliveira, C. G. A., Machado, S. H. M., Brandão, P. S., \& Silva, J. R. G. da. (2016). Prevalência do uso de anfetaminas por caminhoneiros. Acta Biomedica Brasiliensia, 8, 71-82. http://dx.doi.org/10.18571/acbm.14

Berkel, L. V., Crandall, C. S., Eidelman, S., \& Blanchar, J. C. (2015). Hierarchy, dominance, and deliberation: egalitarian values require mental effort. Personality and Social Psychology Bulletin, 41(9), 1207-1222. http://dx.doi. org/10.1177/0146167215591961

Cavieres-Higuera, H., \& Cheyre-Triat, M. J. (2016). Mecanismo de superación de identidad social negativa y legitimación del sistema y del estigma en la población El Castillo, La Pintana, Chile. Revista Geografares, 22(22), 79-87. http:// dx.doi.org/10.7147/GEO22.14752

Confederação Nacional dos Transportes (CNT). (2016). Perfil dos caminhoneiros 2016. Brasília: Autor.

Confederação Nacional do Transporte, Serviço Social do Transporte, \& Serviço Nacional de Aprendizagem do Transporte. (2017). Pesquisa CNT de Rodovias 2017: relatório gerencial. Brasília: Autor.

Cottet, P. (2006). Diseños y estrategias de investigación social: El caso de la ISCUAL. In M. Canales (Ed.), Metodologías de la investigación social: Introducción a los Oficios (pp.185-217). Santiago: LOM.

Friesen, J. P., Kay, A. C., Eibach, R. P., \& Galinsky, A. D. (2014). Seeking structure in social organization: Compensatory control and the psychological advantages of hierarchy. Journal of Personality and Social Psychology, 106, 590-609

Girotto, E., Andrade, S. M., González, A. D., \& Mesas, A. E. (2016). Professional experience and traffic accidents/nearmiss accidents among truck drivers. Accident Analysis and Prevention, 95, 299-304. http://dx.doi.org/10.1016/j. aap.2016.07.004

Girotto, E., Mesas, A. E., Andrade, S. M., \& Birolim, M. M. (2014). Psychoactive substance use by truck drivers: A systematic review. Occupational and Environmental Medicine, 71(1), 71-76. http://dx.doi.org/10.1136/oemed-2013-101452

Greenwald, A. G., \& Banaji, M. R. (2017). The implicit revolution: Reconceiving the relation between conscious and unconscious. American Psychologist, 72(9), 861-871. http://dx.doi.org/10.1037/amp0000238

Guglielmi, O., Magnavita, N., \& Garbarino, S. (2017). Sleep quality, obstructive sleep apnea, and psychological distress in truck drivers: A cross-sectional study. Social Psychiatry and Psychiatric Epidemiology, 53, 1-6. http://dx.doi.org/10.1007/ s00127-017-1474-x 
Haack, P., \& Sieweke, J. (2018). The legitimacy of inequality: integrating the perspectives of system justification and social judgment. Jour. of Manage. Stud., 55, 486-516. http://dx.doi.org/10.1111/joms.12323

Heiphetz, L., Spelke, E.S., Banaji, M.R. (2014). The Formation of Belief-Based Social Preferences. Social Cognition, 32(1), 22-47. http://dx.doi.org/10.1521/soco.2014.32.1.22

Iseland, T., Johansson, E., Skoog, S., \& Daderman, A. M. (2018). An exploratory study of long-haul truck drivers' secondary tasks and reasons for performing them. Accident Analysis and Prevention, 117, 154-163. http://dx.doi.org/10.1016/j. aap.2018.04.010

Jost, J. T., Banaji, M. R., \& Nosek, B. A. (2004). A decade of system justification theory: Accumulated evidence of conscious and unconscious bolstering of the status quo. Political Psychology, 25(6), 881-919.

Jost, J. T., \& Banaji, M. R. (1994). The role of stereotyping in system-justification and the production of false consciousness. British Journal of Social Psychology, 33(1), 1-27. http://dx.doi.org/10.1111/j.2044-8309.1994.tb01008.x

Jost J. T., Gaucher D., \& Stern C. (2015). The world isn't fair: A system justification perspective on social stratification and inequality. In J. F. Dovidio \& J. A. Simpson (Eds.) Handbook of Personality and Social Psychology, Washington: American Psychological Association, pp.317-340

Lincoln, J. E., Birdsey, J., Sieber, W. K., Chen, G. X., Hitchcock, E. M., Nakata, A., \& Robinson, C. F. (2018). A Pilot study of healthy living options at 16 truck stops across the United States. American Journal of Health Promotion, 32(3), 546-553. http://dx.doi.org/10.1177/0890117116670289

Martins, L. T., \& Agli, B. A. V. D. (2014). Valores de motoristas de caminhão: o que lhes causa admiração e indignação? Psicologia: Ciência e Profissão, 34(4), 894-915. http://dx.doi.org/10.1590/1982-370000972013

Ministério do Trabalho (Brasil). (2014). Classificação Brasileira de Ocupações. Brasília: Recuperado em outubro 25, 2019, de http://www.cofen.gov.br/wp-content/uploads/2015/12/CLASSIFICAÇÃO-BRASILEIRA-DE-OCUPAÇÕES-MEC.pdf

Moreno, C. R. C., \& Rotenberg, L. (2009). Fatores determinantes da atividade dos motoristas de caminhão e repercussões à saúde: um olhar a partir da análise coletiva do trabalho. Revista Brasileira de Saúde Ocupacional, 34(120), 128-138.

Moscovici, S. (1996). Psicología de las minorías activas. Madrid: Morata.

Munné, F. (1993). Entre el individuo y la sociedade: Marcos y teorías actuales sobre el comportamiento interpersonal. Barcelona: PPU.

Ortí, A. (1996). La apertura y el enfoque cualitativo o estructural: La entrevista abierta semidirectiva y la discusión de grupo. In M. García-Ferrando, J. Ibáñez \& F. Alvira, (Eds.), El análisis de la realidad social: Métodos y técnicas de investigación p.189-221. Madrid: Alianza Universidad.

Presidente da República (Brasil). (2007). Lei n¹1.442, de 5 de janeiro de 2007. Dispõe sobre o transporte rodoviário de cargas por conta de terceiros e mediante remuneração e revoga a Lei no 6.813, de 10 de julho de 1980. Brasília: Casa Civil. Recuperado em outubro 25, 2019 de http://www.planalto.gov.br/ccivil_03/_ato2007-2010/2007/lei/111442.htm

Sidanius, J., Levin, S., Federico, C., \& Pratto, F. (2001). Legitimizing ideologies: The social dominance. In J. Jost \& B. Major (Eds.). The psychology of legitimacy: Emerging perspectives on ideology justice, and intergroup relation (pp.307-331). Cambridge: Cambridge University Press.

Sidanius J., Cotterill S., Sheehy-Skeffington J., \& Kteily N., Carvacho H. (2017). Social dominance theory: Explorations in the psychology of oppression. In C. Sibley \& F. K. Barlow (Eds.) Cambridge Handbook of the Psychology of Prejudice (pp.149-187) Cambridge: Cambridge Univ Press.

Sobrinho-Santos, C. K., Silva, A. V., Malheiros, A. F., Trindade, R. A., \& Pagan, A. A. (2015). Relatos de caminhoneiros sobre a prevenção do HIV e o material educacional impresso: reflexões para educação em saúde. Ciência \& Educação (Bauru), 21(4), 1011-1030. http://dx.doi.org/10.1590/1516-731320150040014

Williams Jr., D. F., Thomas, S. P., \& Liao-Troth, S. (2017). The truck driver experience: identifying psychological stressors from the voice of the driver. Transportation Journal, 56(1), 54-76. http://dx.doi.org/10.5325/transportationj.56.1.0054

Zigarmi, D., Galloway, F. J., \& Roberts, T. P. (2018). Work locus of control, motivational regulation, employee work passion, and work intentions: An empirical investigation of an appraisal model. Journal of Happiness Studies, 19(1), 231-256. http://dx.doi.org/10.1007/s10902-016-9813-2

Received: November 22, 2018

Final version: August 29, 2019

Approved: September 20, 2019 


\section{ERRATUM}

In article "Being a truck driver in Brazil: From implicit self-stereotypes to system justifi cation" with DOI: 10.1590/1982-0275201936e180139 published in Estudos de Psicologia (Campinas), 2019, 36, e180139 on cover page in article thematic.

\section{Where is read}

PSICOLOGIA DA SAÚDE | HEALTH PSYCHOLOGY

\section{Should read}

SEÇÃO TEMÁTICA | THEMATIC SECTION

PSICOLOGIA E TRABALHO | PSYCHOLOGY AND WORK 